\title{
Clinical and Laboratory Picture in Calves in Rearing with Incidence Bluetongue
}

\author{
Zuzana Lacková ${ }^{1, *}$, Jozef Bíreš², Michal Smaržik ${ }^{1}$ and Martin Tinák ${ }^{3}$ \\ ${ }^{1}$ Clinic of Ruminant Diseases, University of Veterinary Medicine and Pharmacy in Košice, 04181 Košice, Slovak Republic \\ ${ }^{2}$ State Veterinary and Food Administration of the Slovak Republic, Botanická 17, 84213 Bratislava, Slovak Republic \\ ${ }^{3}$ State Veterinary Institute Zvolen, Pod Drahami 918, 96086 Zvolen, Slovak Republic
}

\begin{abstract}
The aim of the study was to analyze clinical and laboratory findings in calves after birth and on the fifth day of age in the farm with the occurrence of bluetongue disease. Presence of a disease has been confirmed in heifers that were imported to Slovakia from France. In August 2008 a total of 132 heifers were imported to Slovakia. Based on serological examinations, presence of antibodies reactive to the virus was proved. In 5 heifers without the presence of virus reactive antibodies, virus was diagnosed. Of 120 calves born, 13 were virologically positive. 10 calves born in the farm were included in the survey. 2 of them were virologically positive, born to serologically negative dams. In 8 control calves born in the same time no antibodies were detected after birth. During clinical examination no clinical signs typical for bluetongue disease were observed. Laboratory examination in the monitoring period showed increase in hepatic profile parameters in virologically positive calves. In virologically negative calves we have detected increased hepatic profile parameters on the 1 st day of life. On the 5th day in this group some of the parameters decreased to the physiological levels. Alterations in the selected biochemical parameters that we have detected in virologically positive and negative animals were likely not influenced by infection with bluetongue.
\end{abstract}

Keywords: Bluetongue, calves, heifers, analysis, laboratory findings.

\section{INTRODUCTION}

The recent arrival in Northern and Western Europe of bluetongue virus (BTV), which causes the ruminant disease 'bluetongue', has raised the profile of this vector-borne ruminant disease and sparked discussions on the reasons for its sudden emergence so far north. This expansion has not happened in isolation and the disease has been expanding into Southern and Eastern Europe for the last decade. This shifting disease distribution is being facilitated by a number of different introduction mechanisms including the movement of infected livestock, the passive movement of infected Culicoides on the wind and, in Northern and Western Europe, an unknown route of introduction [1]. Originally bluetongue was considered as a disease of African continent (first outbreak in The Republic of South Africa in 1876). In 1943 disease was described for the first time outside an African region, in Cyprus. Nowadays disease has been recognized on all the continents except Antarctica. Geographical distribution has been documented in the latitude between $66^{\circ}$ North and $34^{\circ}$ South depending on the occurrence and survival of the vectors $[2,3]$.

The expansion of BTV in Europe has forced a reevaluation of the importance of Palaearctic Culicoides species

*Address correspondence to this author at the Komenskeho 73, Clinic of Ruminants, University of Veterinery Medicine amd Pharmacy in Kosice, 04181 Kosice, Slovak Republic; Tel: 0421948500956;

Fax: 0421556711674; E-mails: lackova_z@azet.sk,dudro@mail.t-com.sk in transmission [2-4], as well as the importance of secondary transmission routes [1], such as transplacental transmission $[1,5-7]$, in facilitating the persistence of the virus.

In the summer of 2006, a bluetongue epidemic started in the border area of The Netherlands, Belgium and Germany, spread within 2 years over large areas of Western and Central Europe, and caused substantial losses in farm ruminants. At that time in Western and Central Europe, only BTV serotype 8 was found, which had never before been found in Europe [8]. The current European outbreak of BTV-8 is believed to have caused greater economic damage than any previous single-serotype outbreak. Although attempts are being made to improve the capacity of European countries to cope with future BTV incursions, the options available are limited by a lack of basic entomological data, limited virological surveillance [1] and limited other laboratory monitoring (serological and biochemical analyses of sick animals).

The aim of this study was to evaluate clinical and laboratory findings in calves after birth to 5 days of age in the farm with bluetongue incidence that was prooved in heifers in the late stage gravidity after the import from France from the area of known BTV incidence.

\section{MATERIALS AND METHODOLOGY}

\section{Animals}

The experiment was conducted in an agricultural farm in South-West region of Slovakia, region Nitra, Horný Jatov (altitude 115 AMSL, latitude $48^{\circ} 8^{\prime} 59.9994 "$, longitude $17^{\circ}$ 
58' 0.0012"). 132 pregnant Holstein heifers, imported from France and their newborn calves (120 calves) were included in the study. In these animals the presence of antibodies against $\mathrm{BT}$ virus and the presence of nucleic acid BT virus (serotypes BTV-1, 6 and 8) was monitored.

For the analysis of clinical and laboratory findings, 10 calves that were born in the farm with the occurrence of bluetongue disease were included in the monitoring. 2 calves originating from serologically negative dams were virologically positive. In 8 control calves born in the same time no anti-BTV antibodies were identified after birth. Clinical and biochemical examinations were carried out in newborn calves.

\section{SAMPLE}

$4 \mathrm{ml}$ of blood were withdrawn from jugular vein for detection of virus nucleic acid ( $1 \mathrm{ml}$ mixed with EDTA) and for determining the presence of antibodies against BT virus (approximately $3 \mathrm{ml}$ of blood). Another $10 \mathrm{ml}$ of blood were taken from 10 calves selected for further examination (biochemical parameters).

\section{Clinical Examination Calves}

Newborn calves included in the survey were examined clinically and also by laboratory methods immediately after birth. Viability, suckling reflex - ability to receive colostrum, body condition, possible body malformations and clinical signs indicating blue tongue disease were assessed.

\section{Laboratory examination}

Blood sampling for the laboratory diagnosis was carried out by puncture of jugular vein in calves before first intake of colostrum and 5 days after birth. Serum activity of the enzymes (AST - aspartateaminotransferase E.C. 2.6.1.1., GGT - gamaglutamyltransferase E.C. 2.3.2.2., CPK - creatinkinase E.C. 2.7.3.2.), serum concentrations of total protein (TP), albumin (ALB), creatinin, total immunoglobulins (CIg), triglycerides (TG) and phosphorus (P) were processed by spectrophotometrical analyser (ALIZÉ, Lisabio, France) and total lipids (TL) were processed by spectrophotometer (Spekol 211, Carl Zeiss Jena, Germany). Calcium (Ca) level was processed by atomic absorbtion spectrophotometric method (Perkin Elmer AAnalyst 100 Atomic Absorption Spectrometer, Rainer Scientific Instruments, United States).

Serological examination for the detection of anti - BTV antibodies (vp 7 protein) was done by ELISA method (ID VET ID Screen Bluetongue Competition Kit for detection of anti-VP7 antibodies by competitive ELISA, ID VET Innovative Diagnostics, France). This kit may be used to examine serum or plasma in sheep, goats, cattle and buffaloes. Purification of viral RNA was carried out from whole blood using BioRobot $^{\circ}$ M48 workstation (MagAttract Viral RNA M48 Kit, Qiagen, Germany). BTV-8 was identified by real-time PCR (BioRobot M48, Qiagen, Germany) [15].

\section{Statistical analysis}

The GraphPad Grism 5 software package was used to calculate the mean values and standard deviations for each parameters. Unpaired t-test and Unpaired t-test with Welch's correction were applied to determine differences between mean values of the data, with $\mathrm{P}<0.05$ considered significant. The comparison yielding the highest $\mathrm{P}$ value 0.05 is reported in cases where multiple t-test were used to identify statistical differences.

\section{RESULTS}

In August 2008, 132 Holstein heifers in the late stage of pregnancy were imported to Slovakia from the area of BTV incidence in France. After serological examination due to the transfer of the animals from the quarantine to the farm, in 5 of 13 examined animals presence of anti-BTV antibodies was proved. Based on these results all imported heifers were examined. Anti-BTV antibodies were recognized in another 19 heifers. In 5 heifers without the presence of antibodies, the presence of the blue tongue virus was found.

All the newborn and stillborn calves were virologically examined. From 120 newborn calves 13 were virologically positive. 7 virologically positive calves descended from seropositive dams and 6 positive calves originated from the serologically negative dams. Most of the virologically positive calves were born in November and December 2008, i.e. 3 months after the import of animals from infected area in France. One of 14 stillborn calves was serologically positive.

During clinical examination no clinical signs typical for bluetongue disease were observed. Calves were viable, with the sufficient suckling reflex without any alterations in body conformation and deformations that are characteristic for the disease. We also haven't noticed any differences in the clinical findings of virologically positive and negative calves.

Laboratory findings during surveillance period in the virologically positive calves showed increase in hepatic profile parameters. AST and CPK serum activity and albumine serum level were increased on the 1st day of life. Increased CPK serum activity, Alb and creatinin serum level were measured also on the 5th day. (Table 1).

In virologically negative calves we have observed increased hepatic profile parameters (AST, CPK, TP, Alb, creatinin) on the 1st day of life. Some of parameters (CPK, Alb) decreased to the physiological levels on the 5th day in this group (Table 1).

During both examinations we have found decrease in total immunoglobulin level (Table 1) and hypercalcaemia, hyperphosphataemia (Table 2). Considering energy profile parameters, we haven't observed any differences between groups of virologically positive and virologically negative calves, except of decreased level of triglycerides in virologically negative calves after birth, that increased to the physiological level on the fifth day of life (Table 3). Alterations in the selected biochemical parameters that we have assessed in virologically positive, and negative animals were likely not influenced by infection with bluetongue, whereas they occurred in negative, as well as in positive calves. We assume that the differences observed in given biochemical parameters were rather caused by other factors such as income and quality of colostrum, or other health problems that were not subject to monitoring.

Statistically significant differences were found when comparing the positive and negative calves. On the first day of life of calves we found statistically significant differences in mean diameter at the significance level $\mathrm{P}<0.05$ in the values of total lipids and creatinine values and CPK serum 
Table 1. Results of Selected Parameters of the Hepatic Profile

\begin{tabular}{|c|c|c|c|c|c|c|c|c|c|}
\hline \multirow{3}{*}{ Parameter } & \multirow{3}{*}{ RH } & \multicolumn{4}{|c|}{ Day 1} & \multicolumn{4}{|c|}{ Day 5} \\
\hline & & \multicolumn{2}{|c|}{$\begin{array}{l}\text { Virological Positive } \\
\quad \text { Calves }(n=2)\end{array}$} & \multicolumn{2}{|c|}{$\begin{array}{l}\text { Virological Negative Calves } \\
\qquad(\mathrm{n}=8)\end{array}$} & \multicolumn{2}{|c|}{$\begin{array}{l}\text { Virological Positive Calves } \\
\qquad(\mathrm{n}=2)\end{array}$} & \multicolumn{2}{|c|}{$\begin{array}{l}\text { Virological Negative } \\
\text { Calves }(n=4)\end{array}$} \\
\hline & & $\mathbf{x}$ & sd & $\mathbf{x}$ & sd & $\mathbf{x}$ & sd & $\mathbf{x}$ & sd \\
\hline AST $\mu \mathrm{kat} / 1$ & $\begin{array}{l}1,3- \\
2,2\end{array}$ & 2,960 & 0,7920 & 4,590 & 6,779 & 1,785 & 0,87 & 0,8475 & 0,1132 \\
\hline GGT $\mu \mathrm{kat} / \mathrm{l}$ & & 0,585 & 0,8273 & 0,026 & 0,07425 & 0,285 & 0,403 & 1,550 & 1,561 \\
\hline CPK $\mu \mathrm{kat} / \mathrm{l}$ & $>5$ & $10,81^{*}$ & 4,228 & $34,13 *$ & 22,24 & 9,655 & 6,710 & 2,690 & 0,5797 \\
\hline TP g/l & $50-70$ & 57,50 & 9,758 & 76,26 & 63,57 & 55,15 & 8,556 & 46,73 & 4,518 \\
\hline Alb g/l & $25-37$ & 41,80 & 4,667 & 43,36 & 16,20 & $42,2 *$ & 5,091 & $36,0 *$ & 2,431 \\
\hline Kreatinín $\mu \mathrm{mol} / 1$ & $>106$ & $70,20^{*}$ & 42,14 & $240,5^{*}$ & 113,7 & 118,2 & 49,43 & 108,5 & 11,88 \\
\hline Clg UZST & $>18$ & 11,30 & 1,280 & 13,53 & 13,57 & 10,53 & 1,810 & 9,155 & 3,266 \\
\hline
\end{tabular}

Number of virologically positive calves is 4 or 8 due to lack of blood serum $\left({ }^{*} \mathrm{P}<0,05\right) ; R H-$ values of healthy animals

Table 2. Results of Selected Parameters of the Mineral Profile

\begin{tabular}{|c|c|c|c|c|c|c|c|c|c|}
\hline \multirow{3}{*}{ Parameter } & \multirow{3}{*}{ RH } & \multicolumn{4}{|c|}{ Day 1} & \multicolumn{4}{|c|}{ Day 5} \\
\hline & & \multicolumn{2}{|c|}{$\begin{array}{l}\text { Virological Positive } \\
\text { Calves }(n=2)\end{array}$} & \multicolumn{2}{|c|}{$\begin{array}{l}\text { Virological Negative Calves } \\
\qquad(n=8)\end{array}$} & \multicolumn{2}{|c|}{$\begin{array}{l}\text { Virological Positive Calves } \\
\qquad(n=2)\end{array}$} & \multicolumn{2}{|c|}{$\begin{array}{l}\text { Virological Negative } \\
\text { Calves }(n=4)\end{array}$} \\
\hline & & $\mathbf{x}$ & sd & $\mathbf{x}$ & sd & $\mathbf{x}$ & sd & $\mathbf{x}$ & sd \\
\hline $\mathrm{Ca} \mathrm{mmol} / 1$ & $2,2-2,8$ & 3,090 & 0,1414 & 3,203 & 0,5028 & 3,180 & 0,4101 & 3,188 & 0,1387 \\
\hline $\mathrm{P}$ mmol/1 & $2,68-3,07$ & 3,450 & 0,9334 & 4,216 & 2,369 & $3,455^{*}$ & 0,4313 & $2,520^{*}$ & 0,1219 \\
\hline
\end{tabular}

Number of virologically positive calves is 4 or 8 due to lack of blood serum $\left({ }^{*} \mathrm{P}<0,05\right) ; R H-$ values of healthy animals

Table 3. Results of Selected Parameters of the Energy Profile

\begin{tabular}{|c|c|c|c|c|c|c|c|c|c|}
\hline \multirow{3}{*}{ Parameter } & \multirow{3}{*}{ RH } & \multicolumn{4}{|c|}{ Day 1} & \multicolumn{4}{|c|}{ Day 5} \\
\hline & & \multicolumn{2}{|c|}{$\begin{array}{l}\text { Virological Positive } \\
\text { Calves }(n=2)\end{array}$} & \multicolumn{2}{|c|}{$\begin{array}{l}\text { Virological Negative Calves } \\
\qquad(n=8)\end{array}$} & \multicolumn{2}{|c|}{$\begin{array}{l}\text { Virological Positive Calves } \\
\qquad(n=2)\end{array}$} & \multicolumn{2}{|c|}{$\begin{array}{l}\text { Virological Negative } \\
\text { Calves }(n=4)\end{array}$} \\
\hline & & $\mathbf{x}$ & sd & $\mathbf{x}$ & sd & $\mathbf{x}$ & sd & $\mathbf{x}$ & sd \\
\hline TG mmol/l & $0,17-0,51$ & 0,2200 & 0,0848 & 0,07625 & 0,1182 & 0,2200 & 0,2263 & 0,2975 & 0,2790 \\
\hline TL g/l & $1,5-4,5$ & $4,185^{*}$ & 0,3041 & $1,675^{*}$ & 0,8008 & 3,085 & 0,9122 & 2,150 & 0,9979 \\
\hline
\end{tabular}

Number of virologically positive calves is 4 or 8 due to lack of blood serum $(* \mathrm{P}<0,05)$; $R H$ - values of healthy animals

activity. On the fifth day of life of calves we found statistically significant differences in mean diameter at the significance level $\mathrm{P}<0.05$ in the values of albumin and phosphorus. When compared to virologically positive calves in the first and fifth days after birth, we found no significant differences in arithmetic averages.

\section{DISCUSSION}

Understanding the spatial dynamics of an infectious disease is critical when attempting to predict where and how fast the disease will spread. The use of simulation modeling for estimating the spread of infectious animal diseases has now become common [9-12]. A wide range of factors related to the ecology of diseases, e. g. enviromental and ecological parameters, are constantly changing and will subsequently induce modifications in the transmission of pathogens [13].

The ways bluetongue can be transmitted among healthy and infected animals may be various. During transport of healthy animals through the bluetongue areas, these animals may be exposed to the infected vector and they may become infected. Also common transport of the infected vector and susceptible animal help to spread disease into the areas that were bluetongue - free before. Risk of BT transmission during transport depends on the opportunity to get infected during transport through the infected area. Animals were transported during August, that is, according to the EU Commission analysis in EU countries, the period with the high risk of virus transmission from infected vector to the susceptible animal. Based on the number of notified BT cases in EU member countries since January 2006 to March 2008, the period of highest occurrence of disease in animals has been in October and November, as it happened also in our case of BT infection in newborn calves of imported heifers from France. This occurrence of infection in given period has been related to the presence and distribution of the vector and change of climate in EU countries [14]. 
Risk of infection depends both on the probability to get bitten by infected Culicoides midges and on the possibility of virus transmission after bite from infected vector to susceptible animal. Use of insecticides and repellents before animal transit movements significantly decreases risk of BT virus transmission during transport, lowers vector density and subsequently number of its bites. Requirement laid down in Council Direction No. 2000/75/EC that animals must be treated with insecticides or repellents 28 days before all transit movements has been the basic requirement for the animal movements from restricted zones [15]. From the certification of the heifers before transit to Slovakia it has been clear that they were treated by insecticides against midges 28 days before transit. This fact considerably decreases the possibility of BTV transmission by imported animals via Culicoides vector. Period of high risk of disease transmission from infected vector to susceptible animal is also called a transmission season. Knowledge of this period is important from the view of decreasing risk of transmission during transit movements by use of suitable protective tools. Based on these facts we can assume that import of the heifers from France to Slovakia was carried out at the beginning of critical period for bluetongue (August 2008).

Latest knowledge related to the BTV-8 circulation in Europe point to the virus transmission not only by vector, but also directly from ruminant to ruminant. Ability to cross the bovine placenta has also been described $[5,16]$. Transmission of terrain strain BTV-8 by transplacental and probably also oral routes was documented. Two seropositive pregnant cows, which were introduced in January 2008 from the Netherlands were found in Northern Ireland. Using detection by PCR method they detected no viral RNA. These cows gave birth to three calves. In these calves, however, RNA was found [17]. In this study viremic calves were born to seropositive and virologically negative dams. In our case virologically positive calves were born to serologically negative and virologically negative dams. Dairy cows are susceptible to BT virus between 60th - 140th day of gravidity [18]. Immunological response of foetus to the BTV infection becomes evident on 150th day of pregnancy and neutralisation antibodies may be found also after 175 days [19]. Youngster is born with the virus-specific antibodies [20]. If foetus is infected in the second half of pregnancy, calf may be born viremic. The course of viremy is the same as in postnatal infection [21]. BT virus nucleic acid was confirmed in 13 newborn calves, i.e. at $10.83 \%$. Results of the study showed in utero infection in $35 \%$ of calves [7].

Negative serological and virological results were required for their transit to Slovakia. These were declared by importer, as stated in Commission Regulation (EC) No. 1266/2007, Annex III. Here we suppose the highest risk of BT transfer to Slovakia within the time of examination and animal transport itself [22]. Vaccination has been suggested as one of the most important control measures for bluetongue disease [23]. In the sense, the limited number of cases reported in livestock despite the circulation observed in ruminants suggest that vaccination seems to be effective to prevent the clinical disease [24].

Vaccination and subsequent revaccination by Bovillis BTV8 vaccine (co. Intervet) was carried out only after detection of positive results for the presence of anti-VP7 (viral outer core protein) antibodies. Whereas after vaccination and subsequent revaccination certain levels of anti-BTV antibodies were produced in heifers, that were passed to the youngsters via collostrum, only presence of BT virus was monitored in calves. Passive transport of anti-BTV antibodies through the epitheliochorial placenta of ruminants is not possible [7].

In cattle and goats, BTV infections are usually subclinical, whereas natural infection of BTV-8 $[6,7,16,25]$ and experimental infection with some BTV strains [26] of pregnant cows during early gestation may result in congenital brain defects, in particular hydranencephaly of the foetuses or calves [27]. Infection with BT in pregnant animals, causes abortions, giving birth to stillborn offsprings or malformated calves and lambs depending on the stage gravidity $[2,5,27$, 28]. Infection of pregnant ewes in the first trimester results in embryonic mortality, resorbtion, abortions or delivery of malformated lambs or lambs with the lowered or missing reflexes (suckling reflex) [20,21]. In virologically positive calves none of the mentioned alterations were observed. We can make a conclusion of the infection in later stages of gravidity.

The results of selected biochemical parameters in virologically positive calves at birth and at 5 day of age, did not show significant differences. Elevated levels of AST and CPK in virologically positive and negative calves could be associated with their development, could indicate alteration of the locomotor system in the postnatal period [29], which could encourage an increase in creatinine at the 5th day old virologically positive calves. Similarly, increases in serum levels of albumin in early development stadium may indicate e.g. hepatopathy, dehydrated calves [29]. Based on the results of biochemical analysis in calves virologically positive and negative calves, we can conclude that these parameters were not affected by the presence of BT.

\section{CONCLUSION}

During clinical examination no clinical signs typical for bluetongue disease were observed. Also no differences in the clinical findings of virologically positive and negative calves were found. Alterations in the selected biochemical parameters that we have detected in virologically positive and negative animals were likely not influenced by infection with bluetongue.

\section{CONFLICT OF INTEREST}

The authors confirm that this article content has no conflicts of interest.

\section{ACKNOWLEDGEMENT}

This study was supported by projects AV 4/2041/08 Surveillance of bluetongue disease in domestic ruminants, initial entomological, clinical-biochemical and virological surveillance in Slovakia and VEGA 1/0940/11 Entomological, climate, clinical-biochemical and virological surveillance of bluetongue disease - surveillance in domestic ruminants.

\section{REFERENCES}

[1] Wilson AJ, Mellor PS. Bluetongue in Europe: past, present and future. Phil Trans R Soc B 2009; 364: 2669-81.

[2] Bires J. Bluetongue diseases - European phenonenon. Slovak Vet J 2006; 6: 346-9. 
[3] Bires J. Bluetongue diseases in sheep. Breeding of sheep and goats. Slovak magazine. Chov oviec a kôz 2007; vol. 4: pp. 10-2.

[4] Saegerman C, Berkvens D, Mellor PS. Bluetongue Epidemiology in the European Union. Emerg Infect Dis 2008; 14: 539-44.

[5] De Clercq K, De Leeuw I, Verheyden B, et al. Transplacental infection and apparently immunotolerance induced by a wild-type bluetongue virus serotype 8 natural infection. Transbound Emerg Dis 2008a; 55: 352-9.

[6] De Clercq K, Van den Bussche F, Vandemeulebroucke E, et al. Transplacental bluetongue infection in cattle. Vet Rec 2008b; 162: 564.

[7] Desmecht D, Bergh RV, Sartelet A, et al. Evidence for transplacental transmission of the current wild - type strain of bluetongue virus serotype 8 in cattle. Vet Rec 2008; 163: 50-2.

[8] Mehlhorn H, Walldorf V, Klimpel S, et al. Bluetongue disease in Germany (2007-2008): monitoring of entomological aspects. Parasitol Res 2009; 105: 313-9.

[9] Russell CA, Smith DL, Waller LA, Childs JE, Real LA. A priori prediction of disease invasion dynamics in a novel environment. Proc Royal Soc B 2004; 271: 21-5.

[10] Keeling MJ. Models of foot-and-mouth disease. Proc R Soc B 2005; 272: 1195-202.

[11] Guitian J, Pfeiffer D. Should we use models to inform policy development? Vet J 2006; 172: 393-5.

[12] Hosseini PR, Dhondt AA, Dobson AP. Spatial spread of an emerging infectious disease: conjunctivitis in house finches. Ecology 2006; 87: 3037-46.

[13] Martin C, Pastoret PP, Brochier B, Humblet MF, Seagerman C. A survey of the transmission of infectious diseases/ infections between wild and domestic ungulates in Europe. Vet Res 2011; 42: 70.

[14] European Food Safety Authority. Bluetongue Serotype 8 Epidemic Bulletin by EFSA BTV Epidemiology Working Group, Bulletin 11, 21 December 2006. Available from: www.efsa.europa.eu/cs/BlobServer/DocumentSet/blu\%20tongue $\% 20$ bulletin $\% 2020 \%$ December \%202006.pdf [cited 2011 Feb 2]

[15] Council Directive 2000/75/ES of 20 November 2000 laying down specific provisions for the control and eradication of bluetongue. Off J Eur Commun 2000; L327: 74-83.

[16] Vercauteren G, Miry C, Van den Bussche F, et al. Bluetongue virus serotype 8 - associated congenital hydronencephaly in calves. Transbound Emerg Dis 2008; 55: 293-8.
[17] Menzienz FD, McCullough SJ, McKeoen IM, et al. Evidence for transplacental and contact transmission of bluetongue virus in cattle. Vet Rec 2008; 163: 203-9.

[18] The Gray Book, Part IV., Foreign animal diseases, Bluetongue and Epizootic Hemorrhagic Disease, 6 vydanie, 1998,. Available from: www.vet.uga.edu/vpp/graybook02/fad/ index.phd [cited 2009 Oct $15]$

[19] Osburn BI. The impact of bluetongue virus on reproduction. Comp Immunol Microbiol Infect Dis 1994; 17 (3-4): 189-96.

[20] Dal Pozzo F, Saegerman C, Thiry E. Bovine infection with bluetongue virus with special emphasis on European serotype 8. Vet J 2009; 182(2):142-51.

[21] Mac Lachlan NJ, Conley AJ, Kennedy PC. Bluetongue and equine arteritis viruses as models of virus-induced fetal injury and abortion. Anim Reprod Sci 2000; 60: 643-51.

[22] Singh EL. The diseases control potentional of embryos. Theriogenology 1987; 27: 9-20.

[23] Commission regulation (EC) No 1266/2007 of 26 October 2007 on implementing rules for Council Directive 2000/75/EC as regards the control, monitoring, surveillance and restriction on movements of certain animals of susceptible species in relation to bluetongue. Off J Eur Commun 2007; L283: 37-51

[24] García - BI, Arenas - MA, Lorca - OC, et al. Role of wild ruminants in the epidemiology of bluetongue virus serotypes 1,4 and 8 in Spain. Vet Res 2011; 42: 88-94.

[25] Bhanubakash V, Indrani BK, Hosamani M, Balamurugan V, Singh RK. Bluetongue vaccines: the past, present and future. Expert Rev Vaccines 2009; 8: 191-204.

[26] Wouda W, Roumen MPHM, Peperkamp NHMT, Vos JH, Van Garderen E, Muskens J. Hydranencephaly in calves following the bluetongue serotype 8 epidemic in the Netherlands. Vet Rec 2008; 162: 422-3.

[27] Lee F, Ting LJ, Jong MH, Chang WM, Wang FI. Subclinical bluetongue virus infection in domestic ruminants in Taiwan. Vet Microbiol 2010; 142: 225-31.

[28] Backx A, Heutink RG, Van Rooj E, Van Rijn PA. Clinical signs of bluetongue virus serotype 8 infection in sheep and goats. Vet Rec 2007; 161: 1-3.

[29] Kraft W, Dürr U. Clinical and laboratory diagnosis in veterinary medicine. Bratislava: Publishers Hajko \& Hajková 2001; p. 380.

Received: May 07, 2012

Revised: July 24, 2012

Accepted: July 25, 2012

(C) Lackova et al.; Licensee Bentham Open.

This is an open access article licensed under the terms of the Creative Commons Attribution Non-Commercial License (http://creativecommons.org/licenses/by-nc/3.0/) which permits unrestricted, non-commercial use, distribution and reproduction in any medium, provided the work is properly cited. 